\title{
HYÖTYÄ JA HYVINVOINTIA KANSALLE
}

\section{0-1900-lukujen vaihteen puutarhan- ja karjanhoidon opaskirjat aineistona}

Taija Kaarlenkaski ja Marjukka Piirainen

1800-luvun loppupuoli ja 1900-luvun alku olivat Suomessa modernisaatiokehityksen aikaa. Yhdistyksiä ja kouluja perustettiin, ja suomenkielisiä sanomalehtiä alettiin lukea enenevässä määrin myös maaseudulla. Nousevan kansallisuusaatteen hengessä sivistyneistö pyrki levittämään kristillisiä ja siveellisiä ajatuksia sekä käytännön tietoa kansan keskuuteen (Liikanen 1987, 132-133; Niemelä 2003). Lukutaidon yleistyminen, kustannustoiminnan ja kirjakauppa-alan kehitys sekä ennen kaikkea kansankirjastojen perustaminen mahdollistivat tiedon ja aatteiden välittämisen myös kirjallisuuden välityksellä (Mäkinen 2003). Yksi valistustoiminnan osa-alue olivat opaskirjat, joita julkaistiin monilta elämänaloilta terveydestä kotitalouteen. Tässä katsauksessa tarkastelemme suomenkielisiä puutarhan ${ }^{1}$ - ja nautakarjanhoidon opas- ja oppikirjoja, jotka on julkaistu 1860-1920-luvuilla. ${ }^{2}$ Aikakausi on kiinnostava, koska tuolloin maanviljelyksessä tapahtui monia uudistuksia: tuotantoa alettiin aktiivisesti suunnata karjanhoitoon aiemman päätuotantosuunnan viljanviljelyn sijasta ja ravinnoksi viljeltävien kasvien valikoimaa pyrittiin laajentamaan puutarhakasveilla (ks. esim. Vihola 1991; Simonen 1961).

\footnotetext{
${ }^{1}$ Puutarhasanasto oli tarkastelujakson aikaan vakiintumatonta. Puutarha-sanan ohella yleisin ilmaus oli kasvitarha, jonka merkitys kuitenkin vaihteli vihannesmaasta koko hyötypuutarhaan hedelmäpuineen ja marjapensaineen. Joskus siihen sisällytettiin myös koristekasvit.

${ }^{2}$ Kielentutkija Raimo Jussila on esittänyt opaskirjallisuuteen kuuluviksi esimerkiksi harrastekirjat, käyttöoppaat, terveyskirjat ja työoppaat. Tarkastelemamme kirjallisuus kuuluu lähinnä jälkimmäiseen ryhmään. Opaskirjallisuuden keskeisiä ominaisuuksia ovat Jussilan mukaan ajantasaisuus, yleistajuisuus, luotettavuus, käytännöllisyys, päivitettävyys ja käyttäjäkeskeisyys. (Jussila 2006, 24-25.)
} 
Pitkälle 1800-lukua Suomessa kirjoitettiin maatalousasioista lähinnä ruotsiksi. Suomenkielistä maatalouskirjallisuutta alkoi ilmestyä 1800luvun puolivälistä alkaen, runsaammin 1890-luvulta lähtien (Valonen 1991, 266). Karjanhoidon alalta ensimmäiset suomenkieliset sanomalehtikirjoitukset ilmestyivät kuitenkin jo 1700-luvun loppupuolella, samoin eläinlääkintään keskittynyt Kristfrid Gananderin Eläinden Tauti-kirja (1982 [1785]; Mäkelä-Alitalo 2003, 592-594).

Ensimmäinen suomenkielinen puutarhanhoitoon opastava kirjanen oli Turun Akatemian professorin Pietari Adrian Gaddin (1768) Lyhykäinen Ja Yxikertainen Neuwo Kuinga Krydimaan Yrttein Kaswannot, Suomen Maasa, Taittaan saatetta tuleundumaan. Seuraava, ruotsalaisen Olaf Enerothin kirjoittama Kaswutarha-kirja Rahwaalle, ilmestyi lähes sata vuotta myöhemmin vuonna 1860. Puutarhaviljelyä alettiin harjoittaa maassamme ensin linnoissa, luostareissa ja 1500-luvulta alkaen kartanoissa. Koti- ja huvilapuutarhojen perustaminen yleistyi 1700-1800 luvulla, ensin vanhimmissa kaupungeissa. Puutarhakulttuuri levisi Suomeen pääosin Ruotsista, joten ruotsinkielinen väestö saattoi hyödyntää naapurimaassa julkaistua kirjallisuutta. (Häyrynen ym. 2001; Ruoff 2003.) Puutarhaoppia haettiin usein myös Saksasta ja saksankieliset puutarhakirjat olivat ammattiväen keskuudessa tärkeitä vielä 1930-luvulla (Merivuori 2001, 256-257; Haapanen ym. 1935, 68-78).

Suomenkielinen puutarhakirjallisuus oli kuitenkin alkuvuosikymmeninään pääasiassa kotimaista alkuperää - myös suurin osa käännösteoksista, sillä ainakin Alexandra Smirnoff ja Ossian Lundén kirjoittivat teoksiaan ruotsiksi. (Alanko \& Kahila 1994, 26-28; Simonen 1961, 428.) Jo 1800-luvulla julkaistiin suomeksi muun muassa lannoitusta ja kasvinsuojelua käsitteleviä erikoisteoksia, ja niitä ilmestyi tasaisesti koko tarkastelemamme ajanjakson ajan. ${ }^{3}$ 1900-luvun alkuvuosikymmeninä puutarhakirjat painottuivat hyötyviljelyyn eli vihannesten, hedelmien ja marjakasvien viljelyn opetukseen. Kansakoulun kasvitarhaopetusta käsitteleviä ja lapsille suunnattuja puutarhakirjoja julkaistiin myös paljon, sillä puutarhaviljelyä uskottiin voitavan levittää kansan keskuuteen erityisesti lasten välityksellä ja koulupuutarhojen antaman esimerkin avulla. Puutarha-alan ammatillistuminen näkyi vähitellen myös puutarhakirjoissa: 1910-luvulta lähtien alkoi ilmestyä laajoja teoksia puutarhanhoidon eri aloilta ja vuonna 1933 julkaistiin ensimmäinen puutarha-alan hakuteos, Suuri Puutarhatietokirja (Ignatius ym. 1933).

1800-luvun lopussa ja 1900-luvun alussa julkaistiin myös useita valistuskirjasarjoja. Niihin kuului pieniä ja hinnaltaan edullisia kansantajuisia opaskirjoja elämän eri alueilta, myös maatalouden ja puutarhanhoidon

\footnotetext{
${ }^{3}$ Puutarhakirjojen julkaisutiedot perustuvat Piiraisen laatimaan bibliografiaan.
} 
piiristä. Sarjojen julkaisijoina toimivat kustannusliikkeet ja erilaiset järjestöt, kuten Kansanvalistusseura, Suomen talousseura ja Marttayhdistys. Esimerkiksi WSOY kustansi Maamiehen käsikirjastoa sekä laajaa Kyläläisten kirjasia -vihkosten sarjaa, Karisto puolestaan Pieni kotikirjasto -sarjaa. ${ }^{4}$

Viime vuosina 1800-luvun sanomalehtien välittämä kuva maalaiskansan elämästä on herättänyt kiinnostusta perinnetieteissä (esim. Stark 2011 ja 2013), mutta maaseutuväestölle suunnattua opaskirjallisuutta on toistaiseksi tutkittu varsin vähän. Maataloushistorioitsija Teppo Vihola on väitöskirjassaan (1991, 40-41) käyttänyt karjanhoito-oppaita yhtenä aineistona kuvaamassa vanhan maatalouden olosuhteita. Historiantutkija Anne Katrine Gjerløff (2009) on tutkinut tanskalaisia 1800-luvun lopun karjanhoito-oppaita ja niissä esiintyviä käsityksiä eläinten hyvästä hoidosta ja hyvästä lypsylehmästä. Anni Leskinen (2007) on käyttänyt kansakoulujen kasvitarha- ja maatalousopetukseen tarkoitettuja oppikirjoja yhtenä lähderyhmänä Suomen historian pro gradu -työssään, jossa hän tutkii kansakoulujen puutarha- ja maatalousopetukseen vuosina 18981939 liitettyjä ihanteita.

Kirjoituksemme tavoitteena on luoda katsaus opaskirjallisuuden käyttömahdollisuuksiin perinteentutkimuksen aineistona. Laura Stark (2013, 236) on pitänyt 1800-luvun sanomalehtiä ja erityisesti itseoppineiden kansankirjoittajien niihin lähettämää materiaalia arkistoihin tallennettuihin kansankuvauksiin verrattuna vaihtoehtoisten näkökulmien tuottajina. Opaskirjoissa kansaa lähestytään erilaisesta asemasta: valistustoiminnan kohteena. Selvitämme katsauksessamme, ketkä opaskirjoja kirjoittivat ja kenelle ne suunnattiin. Tarkastelemme myös, millaista kuvaa suomalaisesta puutarhan- ja karjanhoidosta kirjat tuottivat. Entä millaisena neuvojen vastaanottajat eli "kansa" kuvattiin? Käsittelemme lisäksi sukupuolen tuottamista opaskirjoissa, sillä puutarhanhoito kehittyi uudenlaiseksi alueeksi naisten ja miesten perinteisen toimintakentän välimaastoon, kun taas karjanhoitoon liittyi vahvasti sukupuolittunut työnjako. Menetelmänä käytämme sisällönanalyysiä, eli olemme abstrahoineet aineistoissa esiintyvistä ilmauksista laajempia käsitejärjestelmiä ja teemoja (ks. Tuomi \& Sarajärvi 2004, 111-116). Olemme keskittyneet aineistosta selvimmin erottuviin teemoihin ja kiinnittäneet erityistä huomiota eri kirjoittajilla esiintyviin samantapaisiin näkemyksiin ja ilmauksiin.

\footnotetext{
${ }^{4}$ Suomen kansallisbibliografia Fennica: https://fennica.linneanet.fi/
} 


\section{AINEISTO}

Tarkastelemme kymmentä karjanhoito-opasta ja kymmentä puutarhanhoidon opaskirjaa. ${ }^{5}$ Tutkimusaineiston muodostamisessa eli 1860-1920luvuilla julkaistujen karjan- ja puutarhanhoidon oppaiden kartoittamisessa olemme käyttäneet kirjastojen tietokantoja ja hakuohjelmia, lähinnä Fennica-tietokantaa. Suomenkielisistä puutarhakirjoista on luotu hakuohjelmien avulla bibliografia, johon on koottu tiedot vuoteen 1950 asti ilmestyneistä teoksista. Vuosien 1860-1930 välisenä aikana julkaistiin yli sata erilaista puutarhakirjaa ja niiden lisäksi suuri joukko pienempiä opaslehtisiä. Katsaukseen on valittu teoksia puutarhaviljelyn eri aloilta: hedelmän- ja marjanviljelykirjoja, vihannesten viljelyyn keskittyviä kirjoja sekä yleisteoksia. Kaikissa kuitenkin neuvotaan hyötykasvien viljelyä ja niiden kohderyhmänä - yksin tai muiden ryhmien ohella - on nimen tai esipuheen perusteella suomenkielinen aikuisväestö, "kansa". Tarkastelun ulkopuolelle ovat jääneet esimerkiksi kansakoulun puutarhanhoidon oppikirjat, johonkin puutarhanhoidon erikoisalueeseen kuten kasvinsuojeluun keskittyvät kirjat sekä pelkästään koristekasvien viljelyä käsittelevät kirjat. Puutarhakirjojen kenttä on laajempi kuin karjanhoitokirjojen, minkä vuoksi edustavan otoksen muodostamiseen on kiinnitetty erityistä huomiota. Tarkasteltavaksi on valittu esimerkiksi painosmäärän perusteella tärkeiksi katsottuja kirjoja. Teosten kirjoittajat ja Suomen oloihin sovittajat ovat ajan tuotteliaimpia puutarhakirjojen kirjoittajia ja merkittäviä puutarha-alan toimijoita, joiden intressit ja tavoitteet ovat jossain määrin poikenneet toisistaan. Kirjoja on useilta kustantajilta ja mukana on myös valistuskirjasarjoihin kuuluvia opaskirjoja.

Myös karjanhoidon alalta julkaistiin tarkastelujaksomme aikana paljon erilaista kirjallisuutta. Osassa annettiin ohjeita kaikkien tuotantoeläinten hoitoon ja osa taas oli pieniin erityisaloihin, kuten lannan talteenottoon ja käsittelyyn kohdistuvia opasvihkosia. Karjanhoito-oppaiden kohdalla tavoitteena on ollut löytää joko alan oppilaitosten oppikirjoiksi tai yleisemmin maanviljelijöille suunnattuja kirjoja, joissa keskitytään nimenomaan nautakarjan hoitoon ja konkreettiseen eläinten käsittelyyn. Esimerkiksi maitotaloutta koskevat kirjat on rajattu tarkastelun ulkopuolelle. Myös karjanhoito-oppaita valikoidessa on kiinnitetty huomiota siihen, että mukaan tulee kirjoja keskeisiltä alan kirjoittajilta ja eri kustantajilta.

\footnotetext{
${ }^{5}$ Kirjoittajista Kaarlenkaski on tutkinut karjanhoito-oppaita, Piirainen taas puutarhaoppaita.
} 


\section{OPPAIDEN KIRJOITTAJAT JA VASTAANOTTAJAT}

Aino Sinnemäki on käytösoppaita tarkastelevassa artikkelissaan eritellyt kirjojen kohderyhmiä kolmella eri tasolla. Ensimmäisen tason muodostavat kirjoittajien omat luonnehdinnat siitä, kenelle teksti on osoitettu, toisen taas oppaiden muodostama yleiskuva siitä, millaisessa elämänpiirissä liikutaan. Kolmantena tasona Sinnemäki pitää erilaisia varoittavia esimerkkejä ja paheksuttavien toimintojen kuvauksia, jotka paljastavat kirjoittajien käsityksen kohderyhmänsä todellisesta toiminnasta. (Sinnemäki 1991, 187.) Käsittelemme tässä alaluvussa Sinnemäen esittämää ensimmäistä tasoa: millaiselle yleisölle opaskirjat niiden eksplisiittisen sisällön perusteella suunnattiin. Toiseen ja kolmanteen tasoon paneudumme seuraavassa alaluvussa.

Osa aineistomme kirjoista on karjanhoito- ja puutarha-alan oppilaitosten oppikirjoja, osa taas on suunnattu laajemmin maanviljelijöille ja muille aiheesta kiinnostuneille. Oppi- ja tietokirjan välillä ei aina olekaan selvää eroa (Tommila 1983, 274). Vaikka maatalous- ja karjanhoitokoulujen tavoitteena oli 1800-luvulla kouluttaa ensisijaisesti ammattitaitoisia työnjohtajia suurtiloille, uudenlaisen maatalouden opit levisivät suurviljelmiltä myös pienemmille tiloille (Tuorlahti 1943, 19-20; Niemelä 1996, 83-84). Näin myös oppikirjojen tieto levisi pikkuhiljaa laajemminkin maalaisväestölle. Lisäksi uusien ajatusten levittämiseen osallistuivat merkittävästi eri alueilla toimivat maanviljelysseurat, jotka jakoivat opaskirjoja myös ilmaiseksi. Oppilaitoksista valmistuneista moni sijoittui eri järjestöjen palvelukseen maatalous- sekä puutarha- ja kotitalousneuvojiksi, joiden jakama oppi tavoitti ihmiset näiden kotiympäristöissä. (Niemelä 1996, 105; Niemelä 2003, 491-492; Simonen 1961, 409-421.)

Monet tarkastelemistamme puutarhanhoidon ja karjanhoidon opaskirjoista ovat käännöksiä muissa Pohjoismaissa ilmestyneistä oppaista. Oppia otettiin niin Ruotsista, Norjasta kuin Tanskastakin. Erilaiset maantieteelliset ja ilmastolliset olot vaativat oppaiden sovittamista ja mukauttamista Suomen olosuhteisiin. Puutteellisesta sovittamisesta näitä kirjasia usein kritisoitiinkin. (Ks. Kivistö 2013, 532-535.) Erityisen tärkeää Suomen oloihin sovittaminen oli puutarhaoppaissa. Puutarhakasvien menestymismahdollisuuksista maamme eri osissa ei ollut juuri tietoa, eikä kansa tuntenut puutarhaviljelyn perusteita. Siksi jo ensimmäiseen käännökseen saatettiin lisätä alkuperäisteosta perusteellisemmat tiedot esimerkiksi maan muokkauksesta, lannoittamisesta ja ojituksesta. Käytännön kokemukseen perustuva ammattilaisten tekemä sovitustyö kohotti suuresti teoksen arvoa. (Lindgren 1903; Schübeler 1884; Abelin 1912.) Puutarhaviljelyn yleistyessä ja kokemusten karttuessa tieto lisääntyi. Lisäpainoksiin tehtiin usein tarpeellisia muutoksia uusimman tiedon ja ajankohtaisten 
kysymysten pohjalta. Erityisesti kasvinsuojelu oli aihepiiri, jossa muutos oli nopeaa. (Lindgren 1918, VI-VIII; Pöyhönen \& Pöyhönen 1950, 7-8; Hyvönen 1929, 3-4.)

Pääosa puutarhakirjojen kirjoittajista oli puutarha-alan ammattilaisia: opettajia, neuvojia ja puutarhureita. Joukossa oli myös vankan puutarhaalan osaamisen hankkineita kansakoulun ja seminaarin opettajia. Kirjoittajat olivat aktiivisia vaikuttajia, jotka toimivat yleensä useissa tehtävissä ja luottamustoimissa ja kirjoittivat erilaisiin julkaisuihin. Monilla oli myös oma puutarha-alan yritys. Heillä oli erilaisia erityisen kiinnostuksen kohteita, mutta yhteistä heille oli halu viedä puutarhaviljelyä eteenpäin. (Alanko \& Kahila 1994, 28-49; Simonen 1961.)

Puutarhanhoito sijoittui maaseudun normatiivisen, vaikkakin käytännössä joustavan sukupuolittuneen työnjaon (Östman 2004, 59-72; Löfström 1999) välimaastoon, pirtin ja pellon välille. Ammatillinen puutarhakoulutus oli alusta lähtien mahdollista molemmille sukupuolille, vaikkakin naiset hakeutuivat erityisesti yhdistettyihin kasvitarha- ja talouskouluihin. Seminaarien opiskelijat, jotka saivat opetusta kasvitarhanhoidossa, olivat sekä miehiä että naisia, ja kansakoulujen kasvitarhaopetus kohdistui sekä tyttöihin että poikiin. (Ks. Simonen 1961, 152-197.) Naiset hakeutuivat myös puutarha-alan korkeampaan koulutukseen. Maamme ensimmäinen ylempää puutarhaopetusta tarjonnut oppilaitos, Lepaan puutarhaopisto, aloitti toimintansa vuonna 1912. Vuonna 1935 sieltä oli saanut päästötodistuksen 71 mies- ja 64 naisoppilasta. (Haapanen ym. 1935, 108.) Puutarha-ala tarjosi myös mahdollisuuden edetä uralla monenlaisista lähtökohdista käsin. Esimerkiksi tuottelias puutarhakirjojen kirjoittaja Frans Salonen oli työläistaustainen puutarhuri, joka oli hakenut lisäoppia ulkomailta, kuten tuohon aikaan oli tapana (Aikalaiskirja 1934, 589).

$\mathrm{Ei}$ siis ole ihme, että naiset kunnostautuivat jo varhain myös puutarhakirjojen kirjoittajina. Ensimmäinen heistä oli Alexandra Smirnoff (1838-1913), ruotsalaisen Olof Enerothin opissa ollut pomologi eli hedelmänviljelyn asiantuntija, joka teki alan pioneerityötä selvittäessään maahamme sopivia hedelmälaatuja. Smirnoff kirjoitti useita puutarhakirjoja, mutta hänen pääteoksiaan ovat suomalaisen ja ruotsalaisen pomologian käsikirjat. Hän myös julkaisi suuren määrän artikkeleita eri maiden lehdissä sekä perusti suomenkielisen puutarhalehden, Kaswitarhan. (Ruoff 2007a.) Myös ruustinna Nora Pöyhönen (1849-1938) teki uraa uurtavaa työtä kasvitarhaviljelyn edistämiseksi etenkin Pohjois-Suomen oloissa. Hän halusi levittää kansan pariin tietoa kasvisruoan ja puutarhatyön tuottamasta hyödystä ja perusti vuonna 1892 Haapavedelle naisille tarkoitetun täysin uudenlaisen koulumuodon, yhdistetyn kasvitarha- ja keittokoulun. Nora Pöyhösen yhdessä tyttärensä Maijun kanssa kirjoittamaa Kodin kasvitarhaa 
käytettiin kymmeniä vuosia oppikirjana maatalous- ja emäntäkouluissa. (Ruoff 2007b.)

Siitä huolimatta, että nautakarjanhoito oli 1800-luvun lopulla ja 1900luvun alussa rajautunut naisten työksi (Östman 2004, 59-63), karjanhoito-oppaita kirjoittivat ja käänsivät yksinomaan miehet. Kyse ei kuitenkaan ollut siitä, että tietokirjoittaminen kokonaisuudessaan olisi ollut miesten alaa, sillä puutarhakirjojen lisäksi naiset kirjoittivat myös kotitalous- ja käytösoppaita (Sinnemäki 1991, 189; Heinonen 1998, 139-147). Karjanhoito-oppaiden kirjoittajat ja kääntäjät olivat maatalous- ja karjanhoitooppilaitosten opettajia ja / tai agronomeja. Esimerkiksi sekä oppaiden kirjoittajana että kääntäjänä kunnostautunut Nils Grotenfelt (1846-1902) suoritti agronomin tutkinnon Ruotsissa 1867, ja palattuaan Suomeen hän kehitti Joroisissa sijainneesta kotitilastaan maineikkaan mallitilan. Hän perusti tilalleen meijerikoulun, jota myös johti 20 vuotta ja kehitti suomenkarjan jalostusta. Grotenfelt sai maanviljelysneuvoksen arvonimen vuonna 1880 ja vuosina 1892-1902 hän toimi maanviljelyshallituksen ylijohtajana. (Savolainen 2008.) Karjanhoito-oppaiden kirjoittajat olivat siis akateemisen koulutuksensa perusteella alansa vankkoja asiantuntijoita.

Aineiston vanhin karjanhoito-opas, nimimerkin Sakari Sakarinpoika (oikealta nimeltään Zacharias Cajander) kirjoittama Lyhykäisiä osoituksia Suomen emännille (1865) oli jo nimensäkin perusteella suunnattu naisille, maatilojen emännille. Oppaan alkupuolella käy ilmi, että karjakon työtä ei arvostettu:

Se on tyhmyyttä, kuin pidetään karjakon wirkaa halpana ja huonona, jonkawuoksi tawallisesti ne maamme waimot, jotka waan suinkin muulla tawalla woiwat henkensä elättää, eiwät rupea karjakoksi. Se on tyhmyyttä, sanon wieläkin: sillä minnäpä on waimon kunniallisempi olla kuin karjakkona? Mikäpä työ tuottaa suuremman ilon, kuin karjan hywä korjuu? Lehmä on luonnostansa puhdas, kaunis ja tarpeellinen eläin, kesy hywälle korjaajallensa, joka hänen ruuwasta ja korjuusta huolen aina pitää. (Sakari Sakarinpoika 1865, 2.)

Uudenlaisen asenteen markkinoiminen karjanhoitoa ja lehmiä kohtaan oli tarpeellista, sillä perinteisessä maataloudessa lehmiä pidettiin monin paikoin enemmän viljanviljelyn vaatiman lannoituksen kuin maidontuotannon takia (Rasila 2004, 480-481). Hevosia pidettiin suuremmassa arvossa kuin lehmiä ja ne saivat parasta ravintoa, kun taas lehmille annettiin muun muassa hakattuja olkia, huonompaa heinää, nauriin ja perunan varsia ja akanoita (Talve 1990, 78-81). Kansanomaisissa käsityksissä miehen yhteys lehmään oli tabu: lypsäminen ja navettatyö yleensäkin oli miehelle häpeä, ja miehen lypsämää maitoa voitiin pitää epäpuhtaana. Karjan parista tavattuja miehiä saatettiin jopa epäillä eläimeen sekaantujiksi. Paikoin miehet kuitenkin tekivät karjan ruokintaan 
liittyviä töitä ja loivat lantaa. (Löfström 1999, 149-150; Östman 2004, 66, 70.) Karjanhoidon aseman korottaminen "pelkästä" naisten töihin kuuluvasta ruokatalouden osa-alueesta merkittäväksi elinkeinoksi ja tulonlähteeksi näyttää olevan yksi karjanhoito-oppaiden pyrkimyksistä. Miesten osallistuminen nähtiin jopa välttämättömäksi karjatalouden kehittymisen kannalta:

Meillä Suomessa on karjanhoito näihin saakka ollut miltei
yksinomaan naisten asiana. Edelleenkin tulenee suurelta osalta
näin olemaan, mutta varmaa on, että ellei karjanhoitoa ja
jalostusta pienwiljelyksissä saada koko perheen yhteiseksi
asiaksi, niin että isäntä yhtähywin kuin emäntä on karjastaan
selwillä, ei koskaan täysin hywiin tuloksiin yleisesti päästä.
"Isännän askel pellon höystää, emännän silmä lehmät
lypsättää" on wanhain hywä sana, mutta todellisia
karjanjalostustaloja ei meillä saatane, ennenkuin miehetkin
meillä karja-asioihin tarttuwat samoin kuin muissa maissa, jotka
karjanhoidossa- ja jalostuksessa ovat meistä edellä. (Nylander
1906, 33.)

Nylanderin, Cajanderin ja Poijärven Lypsykarjan hoito -oppikirjassa (1923) kuvattiin karjankasvatuksen tilannetta eri maissa ja tuotiin esille, että esimerkiksi Sveitsissä, Hollannissa ja Tanskassa miehetkin osallistuivat karjanhoitoon. Näiden maiden karjataloutta pidettiin myös erittäin edistyksellisenä. Samassa teoksessa nautakarja oli jo korotettu "kansallispääomaksi" ja "kansamme aineelliseksi turvaksi ja sen henkisen kehityksen pohjaksi". (Mts. 10, 47-65.) Valistuksella pyrittiin näin nostamaan karjanhoidon statusta ja tekemään siitä myös miehille sopivaa työtä (ks. myös Israelsson 2005, 249). ${ }^{6}$

Puutarhakirjoissa lukijoiden puhutteleminen on sukupuolineutraalia: kirjoista ei suoraan havaitse, että ne olisi kirjoitettu miehille tai naisille. Käytäntöön liittyviä huomautuksia on lähinnä työn fyysisyydestä, esimerkiksi: "Kotipuutarhoissa, joissa useimmiten naiset, vieläpä lapsetkin siirtelevät [lavaikkunoita] paikasta toiseen, ovat keveärakenteiset [...] sopivimmat" (Hyvönen 1914, 9). Abelin (1912, 106) puolestaan toteaa, että maalaisemännän tulee huolehtia monista asioista ja hänellä on paljon työtä, minkä vuoksi kirjoittaja antaa neuvoja ainoastaan mahdollisimman helpoista säilöntämenetelmistä. Vakiintunutta sukupuolen mukaista työnjakoa ei siis pyritty murtamaan; ruoanlaitto kuului itsestään selvästi naisille. Puutarhan todetaan yleensä olevan käytännöllisistä syistä perheenemännän hoidossa, joten sen sijainnin tulee olla sellainen, että siellä

\footnotetext{
${ }^{6}$ Sukupuolittunut työnjako näkyi kuitenkin edelleen esimerkiksi maatalous- ja meijerialan koulutuksessa. Suomen ensimmäisen maatalousoppilaitoksen, Mustialan (perustettu 1840), "ylemmän maanviljelysosaston" eli "agronomiosaston" suoritti vuoteen 1908 mennessä 570 oppilasta, joista 7 oli naisia. Sekä miehille että naisille suunnatun "ylemmän meijeriosaston" taas suoritti 156 oppilasta, joista miehiä oli 19. (Tuorlahti 1943, 24-25.) Agronomin tutkinnon suorittaneiden naisten vähäisyys selittää myös naisten puuttumista karjanhoito-oppaiden kirjoittajista.
} 
on helppo piipahtaa kotitöiden lomassa. Alkuaikoina tämä ei kuitenkaan ollut vielä itsestään selvää:

\begin{abstract}
Tässä [vaimon innostamisessa kasvitarhanhoitoon] on toki vielä vaikeuksia voitettava: naisen kasvatus sekä kaupungissa että maalla on vielä sitä laatua, ettei hän suuresti opi tuntemaan luontoa, joka ympäröipi meitä. Ja mikä oppi, paitsi jumalallisten totuuksien tunteminen, olisi tärkeämpi, hedelmiä tuottavampi, vahvistavampi ja jalostuttavampi kuin tämä. Mutta mitä nainen, kuten sanottu, ei vielä taida, sitä voipi hän oppia! (Schübeler $1884,13$.
\end{abstract}

Yleisesti ottaen ei puutarhanhoidosta kuitenkaan tehty kirjoissa jommankumman sukupuolen asiaa, millä epäilemättä helpotettiin uuden asian hyväksymistä. Kaikki perheenjäsenet saattoivat työskennellä puutarhassa yhdessä, kaikille löytyi sieltä sopivaa tekemistä ja jokaisen perheenjäsenen työpanos oli tärkeä.

\title{
VALISTUSTA KANSAN PARHAAKSI
}

Jos tarkastellaan opaskirjojen yleisöstään ja kohteena olevasta työstä luomaa kuvaa, esiin nousee yleinen kansan sivistäminen. Eri alojen neuvonnan ja valistuksen pyrkimyksenä oli päästä eroon kansaa vaivaavista laiskuudesta, epäsiisteydestä ja tuhlaavaisuudesta (Ollila 1993, 3337; Heinonen 1998, 137-138). Aineiston vanhimmassa karjanhoitooppaassa suomalaisen karjatalouden kehnon tilan suurimmaksi syyksi esitetään juuri laiskuus:
Waikka tosin tämän asian laita on hankala saada poistetuksi, kuin se on kansamme perintö-wikoja, jonka näkee siitäkin kuin meidän nykyinen talonpoikainen kansamme, warsinkin Itäsuomessa, wainoten ja ylönkatsoen, wihaa ahkeruutta ja puhtautta, niin en woi olla waiti siitä, mutta kiirehdin kehoittamaan nousewata nuorisoamme, jonka powessa walistuksen tuli ei ole wielä ehtinyt sammua, harjoittamaan tästä lähtein paremmin ahkeruutta ja puhtautta, waikka tietäisimmekin ja tuntisimme esiwanhempiemme aikoinansa ilman näitäkin aikohin tulleen. (Sakari Sakarinpoika 1865, 2.)

Näin suorasukaisia arvioita kansan luonteesta ja ominaisuuksista ei esitetty enää myöhemmissä oppaissa, mutta niissäkin korostettiin jatkuvasti puhtauden, huolellisuuden ja järjestelmällisyyden merkitystä karjanhoitotyössä. Tarvetta neuvonnalle varmasti olikin, sillä 1800-luvun lopulla ja 1900-luvun alussa tuotantoeläinten olosuhteet olivat monilla pientiloilla suorastaan kurjat: navetat olivat ahtaita ja tunkkaisia ja ruokinta usein hyvin puutteellista (Kaarlenkaski 2014; Kaarlenkaski tulossa). Kuten Satu Apo $(2001,202)$ on huomauttanut, tällaisten elinolojen taustalla olleen köyhyyden syinä pidettiin laiskuutta, tietämättömyyttä, raakuutta ja 
nautinnonhalua ennemminkin kuin yhteiskunnallisia rakenteita ja olosuhteita.

Puutarhaväeltä löytyi kuitenkin myös myötätuntoa kansaa kohtaan; ymmärrettiin, että ainainen raataminen ja puutteellinen ravinto estivät ihmisen henkistä kehitystä:

\begin{abstract}
Kaikin paikoin on näyttäytynyt että sopivat ja hyvät ravintoaineet sekä järjestetty talous matkaansaavat ihmisessä suurempaa kestävyyttä ja voimaa, ajatus- ja toimintakykyä, sekä että tämä on ensimäinen askel sillä tiellä, jota on, käytävä, jos mielitään myöhemmin hankkia korkeampaa sivistystä (Schübeler 1884, VI).
\end{abstract}

Riittävä ja terveellinen ravinto oli siis tärkeää kansan ahdingon helpottamiseksi, ja edulliseksi ja ravitsevaksi syötäväksi tiedetyt kasvikset tarjosivat ratkaisun moneen ongelmaan. Työn ja puutteen raskauttamaa aikuisväestöä ei kuitenkaan ollut helppo innostaa uusiin asioihin. Nuori ihminen nähtiin vastaanottavaisemmaksi kuin vanha, joten oppi uskottiin saatavan paremmin perille heidän avullaan. Kansakoulun puutarhaopetuksen puolesta puhuttiin erityisesti 1800-Iuvun lopun kirjoissa. Pian sen jälkeen kasvitarhaopetusta alettiin toteuttaa kansakoulussa myös käytännössä, ja se vakiintui oppiaineeksi 1930-luvun aikana (Leskinen 2007, 88-89).

Puutarhakirjojen pääsisältönä oli puutarhaviljelymenetelmien ja erilaisten kasvien kasvatuksen opettaminen sekä kasvien käyttömahdollisuuksien esittely. Opettamalla kansaa kasvattamaan vihanneksia hallanarkojen viljan ja perunan rinnalla haluttiin kohentaa sen taloudellista tilaa ja ennaltaehkäistä nälänhätää katovuosina. Samalla edistettiin kansan terveyttä ja fyysistä hyvinvointia terveellisemmän ja monipuolisemman ravinnon avulla. Kansa kuitenkin piti kasvitarhanhoitoa herrastaloihin kuuluvana ylellisyytenä, eikä sillä mielestään ollut aikaa eikä varaa kasvitarhanhoitoon. Lisäksi kasviksia pidettiin eläinten ruokana. Kansa ei siis ymmärtänyt omaa parastaan:

\begin{abstract}
Valitettavasti kyllä maanviljelys ja karjanhoito kaikkine mitä siihen kuuluu, tahi sanalla sanoen, koko talouden hoito monin paikoin on niin alhaisella kannalla, ett'ei kasvitarhahoidolle voi uhrata mitään erinäistä huomiota. Monessa talossa ei ainakaan käytännössä ole käsitystäkään siitä tulekista, joka syntyy pennien kokoamalla, vaikka pennistä syntyy markkoja, ja sentähden ei tulla ajattelemaankaan niin vähäpätöistä seikkaa kuin kasvitarhahoitoa. Mietitään vaan mistä suuret ansiot saataisiin eikä tulevaisuudesta pidetä lukua. (Schübeler 1884, 12.)
\end{abstract}

Alexandra Smirnoff (1893) puolestaan näki maanviljelyn ja muun puutarhaviljelyn tilanteen sangen hyvänä, mutta kantoi huolta hedelmänviljelyksen edistämisestä. Hedelmien, etenkin omenien viljely oli ala, johon asetettiin 1900-luvun taitteessa suuria toiveita. Ruotsista ja Norjasta 
saadut kokemukset osoittivat, että hedelmiä oli mahdollista kasvattaa pohjoisemmassa kuin aiemmin oli uskottu. Suurena ongelmana oli kuitenkin maamme olosuhteisiin sopivien lajikkeiden löytäminen.

Jos wertaamme maamme hedelmäwiljelystä maanwiljelykseen huomaamme että maanwiljelijä ammatissaan jo on saawuttanut sen päämäärän, johon me hedelmäwiljelyksen suhteen pyrimme. Hän täydellisesti käsittää miten hyödyllistä on tuntea kaikki ne eri wiljalajit ja niiden toisinnot, ruoholajit, potaattilajit, juurikaswit y. m. mitä Suomessa wiljellään. Walitessaan kaswilajia on hän jo warsin itsenäisellä kannalla, tietää mitkä lajit soweltuwat hänen wiljelemäänsä maanlaatuun, tuntee kauppa-olot ja mitä hän parhaiten saa myydyksi ja asettaa asiansa sen mukaan. Jos silmäilemme kaswitarhaa, näemme että sielläkin on päästy niin pitkälle että wiljellään tunnetuita warmoja ruokakaswia. Samaten on laita kukkamaitten suhteen. Joka kukalla on määrätty nimensä, tiedetään milloin se on kylwettäwä ja milloin se kukkii ja sen mukaan järjestetään kukkaryhmät. Mitä taas hedelmätarhoihin tulee, wallitsee useimmissa wielä epäwarmuus ja sekawuus. Omistaja käyskelee kuin muukalainen ainakin omassa puutarhassaan, mutta näyttääpä siltä kuin alkaisi tämä tietämättömyys wähitellen käydä rasittawaksi. (Smirnoff 1893, 2.)

Yleinen tietämättömyys ja torjuvat asenteet uutta tietoa kohtaan nähtiin siis edistymisen esteinä sekä karjanhoidossa että puutarhaviljelyssä.

\section{KÄYTÄNNÖLLISTÄ NEUVONTAA}

Huonojen olosuhteiden ja kansan takapajuisuuden päivittelyn lisäksi opaskirjat sisälsivät myös hyvin käytännönläheisiä ohjeita sekä elinkeinojen kehittämisen hyödyllisyyden perusteluja. Puutarhanhoidon hyöty syntyi monista tekijöistä. Itse kasvatettu ruoka vähensi elintarvikkeiden ostotarvetta, mutta myös puutarhatuotteiden myynti ja siemenviljely tarjosivat monenlaisia mahdollisuuksia. Puutarhaviljely oli myös edullista. Se ei vienyt pelloilla tarvittavaa miestyövoimaa, koska fyysisesti kevyempänä sitä saattoivat tehdä myös naiset, vanhukset ja lapset. Puutarhanhoito oli mahdollisuus, joka oli lähes kaikkien ulottuvilla. Sen aloittaminen ei vaatinut runsasta tietomäärää tai rahallisia uhrauksia, vain tiedon sen tarjoamista mahdollisuuksista, pienen maapalan ja kiinnostusta tarttua työhön.

Lannoitusaineiden puute oli tuottavan maanviljelyksen jarruna keinolannoitteiden yleistymiseen asti (Östman 2004, 49-51), eikä viljelyskelpoista maatakaan ollut aina helposti tarjolla. Puutarhaviljelys vaati samoja resursseja kuin maatalous, mutta puutarhakirjoissa pyrittiin selvästi ehkäisemään vastakkainasettelua maanviljelyksen kanssa. Maan 
ravinnevarat tehokkaimmin hyödyntävä vuoroviljely ${ }^{7}$ oli itsestään selvä peruslähtökohta kaikissa vihannesviljelyä käsittelevissä kirjoissa. Aiemmin hyödyntämättömien eloperäisten jätteiden, kuten taloustähteiden ja makkilannan käsittely ja käyttö kasvimaalla oli myös tärkeä osa-alue etenkin vanhimmissa kirjoissa. Taloudellisuus ja viljelyn järkiperäisyys olivat puutarhakirjoissa korostettuja asioita, joissa kansalla oli opittavaa:

\begin{abstract}
Tekisipä mieleni väittää, että liiallinen uskaliaisuus on hedelmänviljelystä maassamme jarruttanut ainakin yhtä paljon kuin haluttomuus. Mitäpä muuta sanoisi siitä lapsekkuudelle vivahtavasta huolettomuudesta, jota monet hedelmätarhamme perustajistaan toteavat. (Hyvönen 1914, 106.)
\end{abstract}

Kasvisten, marjojen ja hedelmien kasvatus ei myöskään hyödytä, ellei niitä käsitellä asianmukaisesti. Huolta kannettiin hedelmien ja kasvisten oikeaoppisesta korjuusta, lajittelusta ja säilyttämisestä sekä myyntiin kasvatettaessa kauppakunnostuksesta. Sato tuli saada säilymään, ja se tuli käyttää järkevästi.

\begin{abstract}
Meidän maassamme on ikävä kyllä juuri [puutarhan] tuotteiden taloudellinen käytäntö enin takapajulla. Jos puutarhan herneet ja pavut antavat tavallista runsaamman sadon, sallitaan niiden kypsyä pilalle, ja milloin taas puut hedelmien painosta notkuvat, kuten esim. v. 1906 tapahtui, silloin annetaan kotieläinten herkutella mehevillä hedelmillä. Ylellisyyden suloisina päivinä unohdetaan, että voi seurata myöskin "katovuosi", vieläpä heti tämän rikkaan vuoden jälkeenkin, ja vasta sitten, kun on liian myöhäistä ja puute näyttää nääntyneet kasvonsa, muistetaan, miten hyvä olisi ollut, jos edelliseltä runsaalta vuodelta jotakin olisi säästössä. (Abelin 1912, 99-100.)
\end{abstract}

Puutarhatuotteiden säilömisen ja käytön opettaminen liittyivät läheisesti viljelyoppiin. Kaikki tarkastellut kirjat antavat ohjeita tuotteiden varastointiin ja hyvin monet myös säilöntään tai ruoanlaittoon. Kasvisruoan terveellisyys, edullisuus, maukkaus ja monipuolisuus tuotiin esiin, mutta painotukset vaihtelivat kirjoittajien välillä. Myös suhtautuminen tuotteiden myyntiin vaihteli: monet korostivat oman käytön ensisijaisuutta, mutta mahdollisuus ansioihin tuotiin kuitenkin vahvasti esille - Smirnoffilla (1893) jopa ainoana perusteena. Keittiökasviviljelyksen tuli etenkin alkuvaiheessa olla taloudellisesti kannattavaa, koska onnistumisen kokemukset ja mahdollisimman suuri hyöty saivat parhaiten aikaan viljelyharrastusta. Siksi kasvitarhasta tuli tehdä vain sen kokoinen että sen varmuudella jaksoi hoitaa.

Ei liene liiaksi vaadittua, jos pienimmissäkin kasvitarhoissa aluksi istutettaisiin edes yksi nimikkopuu [hedelmäpuu] kutakin perheen jäsentä kohti. Mutta vähänkin edistyneemmissä

\footnotetext{
7 Vihannesmaan vuoroviljelyssä eri kasviryhmiä viljellään niiden ravinteiden tarpeen mukaisessa järjestyksessä ja paikkaa vaihdetaan vuosittain. Menetelmä poikkeaa maataloudessa käytetystä vuoroviljelystä (ks. Östman 2004, 45-48).
} 
viljelyksissä niitä tulisi olla useampia, ainakin kun jonkin verran kokemusta on saavutettu. Oman kodin kulutuksen tyydyttäminen on lähin päämäärä, mutta hyvin helposti voi viljely myöhemmin sen ohella muodostua hyväksi rahalliseksi tulonlähteeksi sellaisilla seuduilla, missä myyntimahdollisuuksia on olemassa. [...] Varmaa on, että kunhan kerran päästään siihen, että jokainen hedelmäviljelyä harrastava hankkii itselleen kirjallisuuden ja neuvojain avulla tarpeelliset ohjeet ja tiedot, jotta säästyisi masentavista erehdyksistä, jotka nyt vielä valitettavasti ovat aivan yleisiä, laajenee hedelmäviljelys kodeissamme omasta painostaan saavuttaen ennen kuulumattoman kukoistuskauden. (Pöyhönen \& Pöyhönen 1927, 42.)

Kirjoittajille oli yhteistä luja usko puutarhaviljelyn kykyyn tuottaa hyvinvointia harjoittajilleen. Puutarhanhoidossa taloudellinen ja terveydellinen hyöty yhdistyivät, ja puutarhanhoito tuotti mielihyvää monin eri tavoin. Puutarha opetti hoitajaansa palkitsemalla huolenpidon runsailla antimillaan. Ne olivat kaikkien tavoitettavissa, sillä vaatimattomistakin lähtökohdista saattoi päästä viljelyn alkuun ja edetä vähitellen taidoissa. Siten puutarha toimi edistyksen välineenä ja auttoi kansaa katsomaan luottavaisesti tulevaisuuteen.

Myös nautakarjanhoito-oppaissa lähdettiin liikkeelle käytännöllisistä perusteista. Useissa oppaissa käsiteltiin eläinten anatomiaa ja kaikissa annettiin seikkaperäisiä ohjeita ruokinnasta, samoin sopivista olosuhteista navetassa. Myös hyvien lypsylehmien ominaisuuksien tunnistamista sekä karjan jalostamista neuvottiin. Entä millaisina eläimet ja ihmisten ja nautojen suhteet näyttäytyivät karjanhoito-oppaissa? Muutamissa oppaissa viitattiin käsitykseen eläimestä koneen kaltaisena:

Karjanhoidon asema maanwiljelyksessä käsitetään aina
oikeimmin, kun pidetään eläimiä maanwiljelykseen kuuluwina
e I ä w i n ä k o n e i n a, mitkä hywäkseen käyttäwät kaikki
ne tuotteet, joita luonnollisessa muodossaan ei woida myödä.
Nawetta on siinä tapauksessa tehdas, mihin maanwiljelijä
hankkii niitä rehuaineita, jotka owat lihan, maidon y.m.
tuottamista warten halwimmat raaka-aineet. Ei ole kauan
kulunut siitä ajasta, jolloin jotenkin yleisesti katsottiin
lypsykarjan pitoa "wälttämättömäksi pahaksi". Nyt on kuitenkin
asianlaita toinen. Kokemuksesta tiedetään nim. että maidon
tuotanto on maanwiljelijän paras tulolähde. (Hallenborg 1904,
10.)

Ruotsalaisen professorin Carl Adolf Lindqvistinkin teoksessa Karjanhoidon perusteet $(1886,2)$ nimitettiin eläinten ruumiinosia "ruumiin koneiksi". Samantyyppiseen ajattelutapaan viittaa myös lehmän esittäminen "järjettömänä luontokappaleena" (Sakari Sakarinpoika 1865, 24). Nautojen käsittäminen koneen kaltaisina oli osa aikansa edistysuskoa ja modernisaatioprosessia. Kuten edellä Hallenborgin lainauksen lopussa tulee esille, navetta oli muuttumassa "välttämättömän pahan" tyyssijasta moderniksi 
tehtaaksi, jonne hankittiin "halpoja raaka-aineita" "parhaan tulonlähteen" saamiseksi. (Ks. Israelsson 2005, 74-75.) Tieteen ja tekniikan edistymisen myötä koneanalogiaa hyödynnettiin myös muiden alojen neuvonnassa: esimerkiksi Emäntälehdessä verrattiin kotia koneeseen, jonka jokaisesta osasesta on huolehdittava hyvien tulosten saamiseksi (Ollila 1993, 38; ks. myös Heinonen 1998, 138 viite 159).

Suomalaisten hevossuhteiden kulttuurisia malleja tutkinut Riitta-Marja Leinonen (2013, 38, 241-244) on yhdistänyt hevosten käsittämisen koneen kaltaisina niiden huonoon kohteluun: Iyömiseen ja kohtuuttomien työsuoritusten vaatimiseen. Karjanhoito-oppaissa kuitenkin poikkeuksetta painotettiin eläinten hyvää kohtelua siitä huolimatta, että nautoja verrattiin koneisiin. "Hellää hoitoa" (Oljelund 1877, 22), "lempeää ja ystävällistä kohtelua" (Sunila 1898, 18), jopa kohtelemista "rakkaudella" (Grotenfelt $1892,10)$ korostettiin. Taustalla oli käsitys siitä, että tällainen eläinten käsittely edistää myös ihmisen etua:

Huono eläinten kohtelu osottaa aina raakuutta ja
siwistymättömyyttä sekä huonoa wäliä hoitajan ja eläinten
kesken. Jos hoitaja eläimestään pitää ja eläimet hoitajastaan,
eiwät koskaan huutaminen wihastuminen, potkiminen tai
lyöminen tule kyseeseen. Ilman oikeata hywää suhdetta
eläimiin emme woi niiltä hywää tuotantoa saada. Huonosti
kohdeltu eläin käy araksi tai wihaiseksi. Arkuus ja wiha
synnyttäwät häiriötä hermostossa. Hermoista riippuu ruumiin
aineenvaihdos, siis myöskin rehunkäyttö ja lypsy. Jo pelkkä
inhimillisyys welwoittaa meitä kohtelemaan eläimiä hywin,
mutta sitä waatii samalla oma etumme. (Nylander 1907, 41.)

Eläinten hyvä kohtelu liitettiin siis sivistykseen. Myös varhaiset eläinsuojeluaatteesta kirjoittaneet valistajat toivat esille, että kyse oli toiminnasta ihmisen parhaaksi: eläinten huono kohtelu aiheutti raakuutta, ja huonon kohtelun väheneminen poisti raakuutta myös ihmisten keskinäisissä suhteissa (Nieminen 2001, 9-10). Kuitenkin oppaissa vedottiin myös hyötyajatteluun. Kuten Nylander edellä huomauttaa, kaltoin kohdeltu eläin tulee araksi ja vihaiseksi, eikä silloin myöskään tuota hyvin.

\section{LOPUKSI}

Karjanhoito- ja puutarhaoppaiden tarkastelu osoittaa, että elinkeinot ja niiden uudistaminen valjastettiin osaksi kansan sivistysprojektia. Varhaisten opaskirjojen tavoitteena oli erityisesti kohentaa kansan elinoloja. Kansa tuli saada toimeliaammaksi ja kykeneväksi auttamaan itseään, ja avaimena tähän toimi tieto. Opaskirjat eivät olleet vain yksittäisten neuvojen kokoelmia, vaan ne tarjosivat selkeän kokonaiskuvan opastettavasta asiasta. Myöhemmissä kirjoissa valistuspuhe väheni, ja ne keskittyivät tekniikoiden opettamiseen. 
Esimerkiksi 1920-luvulla käytetyssä karjanhoidon oppikirjassa erilaisten ravintoaineiden koostumusta ja ravintoarvoja selvitettiin jo hyvin seikkaperäisesti.

Puutarhanhoidolle esitettiin kirjoissa runsaasti rationaalisia perusteluita. Aineellisen hyödyn tuottamisen lisäksi sen nähtiin myös kehittävän ihmisessä monenlaisia henkisiä ominaisuuksia kuten ahkeruutta, kärsivällisyyttä ja järjestelmällisyyttä. Puutarhatyö ja sen tuottama hyvinvointi toimivat perhettä yhdistävänä tekijänä edistäen jopa raittiutta. Puutarhakasvien todettiin myös luovan viihtyisyyttä ja kodikkuutta ympäristöönsä. Siihen ei tarvita runsaita koristekasvi-istutuksia, sillä siisti, kasvein ja kukkasin somistettu asunnon ympärys hyvin hoidettuine kasvimaineen on miellyttävä ja soma, vaikka olisi vaatimatonkin. Sellaisesta kodista välittyy ohikulkijallekin tieto siitä, että myös asunnon sisäpuoli on kodikas ja siellä vallitsee siisteys ja järjestys. Leskisen (2007, 92-93) tarkastelemissa kansakoulukirjoissa annetaan puutarhaviljelylle aineellisia, kasvatuksellisia sekä terveyteen, kauneuteen ja hyvinvointiin liittyviä perusteluja. Myös laajemmasta, erityyppisiä puutarhakirjoja sisältävästä aineistosta tehdyssä tarkastelussa (Piirainen, tulossa) erottuu selvästi kasvatuksellinen diskurssi. Tässä katsauksessa tarkastellut kirjat vetosivat kuitenkin ensisijaisesti lukijoidensa käytännöllisiin tarpeisiin ja kasvatuspuhe oli sivuosassa.

Kasvitarha vaati parempaa hoitoa kuin pelto, mutta siitä oli myös mahdollista saada huomattavasti enemmän tuottoa. Kynnystä puutarhakasvien viljelyyn madallettiin pitämällä huolta siitä, ettei sen tarvinnut kilpailla samoista resursseista - maasta, lannoitteista ja työvoimasta - maanviljelyksen kanssa. Tuoton edellytyksenä oli hyvä hoito, joka perustui ahkeruuteen ja tietoon kasvien tarpeista. Maan kasvukunnosta huolehtiminen oli viljelyn lähtökohta; maan ojittaminen ja muokkaaminen sekä maanparannusaineiden ja lannoitteiden hankkiminen olivat työtä, joista seurasi ruhtinaallinen palkkio. Samoin karjanhoidon edistämistä perusteltiin taloudellisilla syillä, paremmalla maidontuotoksella ja siitä saatavilla tuloilla. Hyvä hoito korostui myös karjanhoito-oppaissa: paitsi että se paransi eläinten tuotantokykyä, eläinten hyvän kohtelun nähtiin edistävän sivistynyttä käytöstä inmistenkin kesken. Oikean tiedon ja "järkiperäisyyden" tuli syrjäyttää kansanomaiset väärät käsitykset ja toimintatavat.

Karjanhoito- ja puutarhaoppaiden kohderyhmissä on havaittavissa jonkin verran eroja. Puutarhaoppia pyrittiin levittämään myös lasten ja nuorison kautta, mutta karjanhoito-oppaat olivat pelkästään aikuisille tai vähintään nuorille aikuisille suunnattuja. Karjanhoitoa pyrittiin korostetusti esittämään myös miehille sopivana alana, eli muuttamaan perinteistä sukupuolittunutta työnjakoa. Hyötykasvien viljely oli sen sijaan uusi elinkeino, jolla ei ollut taakkanaan samanlaista perinteiden painolastia. 
On todennäköistä, että ulkomaisista teoksista käännettyjen oppaiden luoma kuva kansasta on peräisin alkuteoksista. Kirjojen kääntäjien ja sovittajien voi kuitenkin olettaa hyväksyneen niiden ajatukset ja teksteistä voi havaita, että kirjoittajat tuntevat oman alueensa olosuhteet hyvin. Mikäli silti haluttaisiin selvittää, kenen ääni teksteissä kulloinkin kuuluu, olisi kirjoja verrattava alkuperäisiin teoksiin. Vaikka kansan takapajuisuutta ja maanviljelyn alkeellisuutta paheksuttiin useissa oppaissa, nähtiin kansa myös oppimiskykyisenä. Opaskirjallisuuden tarkastelun lisäksi olisikin mielenkiintoista tutkia aikalaisaineistoista myös elinkeinovalistuksen vastaanottoa (vrt. Mikkola 2009). Aikakauden sanomalehdet ja kansankirjoittajien omaelämäkerralliset tekstit voisivat kenties valaista tätä näkökulmaa. Opaskirjat kuitenkin kertoivat kansalle, millainen se oli. Kirjat osoittivat vallinneen tilanteen ja siinä ilmenevät epäkohdat. Ne myös maalasivat kuvaa paremmasta tulevaisuudesta ja tarjosivat lukijalle keinot sen saavuttamiseksi.

\section{TUTKIMUSAINEISTOT}

Karjanhoito-oppaat julkaisujärjestyksessä vanhimmasta uusimpaan

Sakari Sakarinpoika (Zacharias Cajander) 1865: Lyhykäisiä osoituksia Suomen emännille lehmä-karjan- sekä maidon-hoidossa ja juuston teossa. Toinen, lisätty ja parannettu painos, jonka toimitti A. Manninen. Kuopio: A. Mannisen ja Fr. Ahlqvistin kirjapaino.

Oljelund, August 1877: Karjanhoito ja maitotalous Suomen maatawiljelewälle kansalle. Suomentanut J.B. Joensuu: S. Piipposen kustannuksella.

Lindqvist, Carl Adolf 1886: Karjanhoidon perusteet. Mukaillut sekä Suomen oloihin sovittanut ja karjakko-kouluille oppikirjaksi muodostanut Nils Grotenfelt, Järvikylän karjakko-koulun johtaja. Kolmas tarkastettu painos. Helsinki: G.W. Edlund.

Grotenfelt, Nils 1892: Karjanhoidon ja maitotalouden oppikirja kiertäviä karjakko- ja meijerikouluja, karja- ja meijeri-taloja sekä alempia karjakko- ja meijeri-oppilaitoksia varten. Mikkelin läänin maaviljelysseuran käskystä ja kustannuksella. Toinen painos. Helsinki: WSOY.

Sunila, J.E. (suom.) 1898: Neuvoja ja ohjeita karjanhoidossa. Oloihimme sovitettu suomennos. Helsinki: Otava. 
Hallenborg, J.F. 1904: Lypsykarjan hoito. Ensi palkinnon saanut kilpakirjoitus. Kolmannesta painoksesta mukaillen suomentanut J.E. Sunila. Porvoo: Werner Söderström Osakeyhtiö.

Nylander, Hannes 1906: Ohjeita karjataloudessa pienwiljelijöille I. Karjanjalostus ja kaswatus. Porvoo: Werner Söderström Osakeyhtiö.

Nylander, Hannes 1907: Ohjeita karjataloudessa pienwiljelijöille II. Lypsylehmien ruokinta ja hoito. Porvoo: Werner Söderström Osakeyhtiö.

Cajander, E. 1918: Karjatalouden järjestäminen ja johto. Porvoo: WSOY.

Nylander, Hannes, Cajander, E. \& Poijärvi, IImari 1923: Lypsykarjan hoito. Neljäs, uusittu painos. Helsinki: Otava.

Puutarhaoppaat julkaisujärjestyksessä vanhimmasta uusimpaan

Eneroth, Olli [Olaf] 1860: Kaswutarha-kirja Rahwaalle. Kaswutarha-kirja Rahwaan hyödyksi. Ruotsiksi kirjoitettu. Olli Enerothilta, Ruotsin Kasvutarha-yhteyden Kotomaan Sihtieri ja Opettaja sen oppilaiskoulussa. Suomentanut F. v. P. Turku: J. W. Lilljan kirjapaino.

Schübeler, F.C. 1884: Kasvitarha. Sen hyöty ja arvo taloudessa. Kirjoittanut kansaa varten Tr. F. C. Schübeler. Toisesta norjalaisesta painoksesta mukailemalla suomentanut Arvid Th. Genetz. Sortavala: C. W. Alopæus.

Smirnoff, A. [Alexandra] 1893: Puuhedelmien wiljelemisesta Suomessa sekä käytännöllisiä neuwoja wasta-alkawille. Kansanvalistus-seuran toimituksia LXXXII, Yhdeksästoista wuosikerta. Ensimmäinen wihko. Helsinki: Kansanvalistus-seura.

Lindgren, Erik 1903: Kasvitarhakirja. Neuvoja keittiökasvien, hedelmäpuiden, marjapensasten, puistopuiden ja-pensaiden, ulkoilma- ja huonekukkien viljelemiseen, ohjeeksi jokaiselle kasvitarhanhoidon harrastajalle. Seitsemännestä tarkastetusta ja lisätystä painoksesta Suomen oloihin mukaillut Klas Stening, Mustialan puutarhuri. Suomentaneet K. Korpela, pitäjän apulainen ja Aug. Viksten, kansak. opettaja. Porvoo: Werner Söderström.

Abelin, Rudolf 1912: Pikkupuutarha. Neuvoja hedelmäpuiden, marjapensasten, keittiö- ja koristekasvien viljelemiseen ja hoitoon. Suomen oloihin sovittaneet B. W. Heikel ja Ossian Lundén. Suomentanut Aug. Heliä. Toinen, korjattu painos. Helsinki: Kustannusosakeyhtiö Otava. 
Vanamo, Kaarlo 1912: Keittiökasvien viljelys. Opas alotteleville. Hämeenlinna : Arvi A. Karisto.

Hyvönen, M. [Matti] 1914: Kotipuutarhuri. Käytännöllinen opas keittiökasvien, hedelmä- ja marjakasvien sekä kaunistekasvien hoitajille. Helsinki: Kustannusosakeyhtiö Otava.

Salonen, Frans \& Kurimo, Anna 1915: Kotien puutarhakirja ja lyhyt säilöönpano-opas. Ohjeita keittiö-, marja-, hedelmä- ja koristekasvien viljelyyn ja hoitoon sekä kasviksien säilyttämiseen. Terveyden kirjasia n:o 8. Salo: "Terveys".

Kalervo, Kalle 1925: Käytännöllinen puutarhanhoito. Puutarhanhoidon opas sekä yksityistarvetta että seminaareja, maamies- ja emäntäkouluja, kansanopistoja ja kesäkursseja varten. Toinen painos. Helsinki: Kustannusosakeyhtiö Kirja.

Pöyhönen, Nora \& Pöyhönen, Maiju 1927: Kodin kasvitarha. Opas keittiökasvien, marjain, hedelmien, koristepuiden ja -pensaiden, avomaan kukkien ja huonekasvien viljelemiseen. Helsinki: Kustannusosakeyhtiö Otava.

KIRJALLISUUS

Aikalaiskirja 1934. [online] <http://runeberg.org/aikalais/1934/0587.html> [ 15.7.2014.]

Alanko, Pentti \& Kahila, Pirkko 1994: Ukonhattu ja ahkeraliisa. Perinteiset hyöty- ja koristekasvit. Helsinki: Kustannusosakeyhtiö Tammi.

Apo, Satu 2001: Viinan voima. Näkökulmia suomalaisten kansanomaiseen alkoholiajatteluun ja -kulttuuriin. Helsinki: SKS.

Gadd, Pietari Adriani [Pehr Adrian] 1768: Lyhykäinen Ja Yxikertainen Neuwo Kuinga Krydimaan Yrttein Kaswannot, Suomen Maasa, Taittaan saatetta tuleundumaan. Turku: J. C. Frenckell. [online] < http://s1.doria.fi/helmi/bk/rv/fem970239/ > [27.9.2014.]

Ganander, Kristfrid 1982: Eläinden Tauti-Kirja. Tampere: Lääketieteellinen oppimateriaalikustantamo. [1785]

Gjerløff, Anne Katrine 2009: Creating the Comfortable Cow - Discourses on Animal Protection and Production in late 19th-century Danish Agriculture. - Holmberg, Tora (toim.), Investigating Human/Animal Relations in Science, Culture and Work. Uppsala: University of Uppsala. 114-121. 
Haapanen, Arvo, Collan, Olavi \& Salmenlinna, S. S. 1935: Lepaan puutarhaopisto 1910-1935. Porvoo: WSOY.

Heinonen, Visa 1998: Talonpoikainen etiikka ja kulutuksen henki. Kotitalousneuvonnasta kuluttajapolitiikkaan 1900-luvun Suomessa. Helsinki: Suomen Historiallinen Seura.

Hyvönen, M. 1929: Kotipuutarhuri. Helsinki: Kustannusosakeyhtiö Otava.

Häyrynen, Maunu, Eskola, Taneli, Frondelius, Satu \& Leskinen, Pekka (toim.) 2001: Hortus Fennicus - Suomen puutarhataide. Helsinki: Viherympäristöliitto ry ja Puutarhataiteen seura ry.

Ignatius, Gustaf, Salonen, Frans, Collan, Olavi \& Haapanen, Arvo (toim.) 1933, Suuri puutarhatietokirja I-II. Aakkosellinen hakuteos. Porvoo: Werner Söderström Osakeyhtiö.

Israelsson, Carin 2005: Kor och människor. Nötkreatursskötsel och besättningsstorlekar på torp och herrgårdar 1850-1914. Hedemora: Gidlunds förlag.

Jussila, Raimo 2006: Mitä tietokirjallisuus on. - Jussila, Raimo, Ojanen, Eero \& Tuominen, Taija (toim.), Tieto kirjaksi. Helsinki: Kansanvalistusseura. 12-32.

Kaarlenkaski, Taija [tulossa]: Cattle Tending in the "Good Old Times": Human-Cow Relationships in Late Nineteenth-Century and Early Twentieth-Century Finland. - Nyman, Jopi \& Schuurman, Nora (eds.), Affective Animals: Relational Approaches to Human-Animal Encounters.

Kaarlenkaski, Taija 2014: Lehmä luonnon ja kulttuurin rajalla. Karjanhoidon eläin- ja ympäristösuhteet 1800-luvun lopun ja 1900-luvun alun Suomessa. - Piela, Ulla \& Knuuttila, Seppo (toim.), Ympäristömytologia. Helsinki: SKS. 282-300.

Kivistö, Sari 2013: Oppaita ja käytännön tietokirjoja. - Paloposki, Outi \& Riikonen, H. K. (toim.), Suomennetun tietokirjallisuuden historia 1800-luvulta 2000-luvulle. Helsinki: SKS. 532-551.

Leinonen, Riitta-Marja 2013: Palvelijasta terapeutiksi. Ihmisen ja hevosen suhteen muuttuvat kulttuuriset mallit Suomessa. Oulu: Oulun yliopisto.

Leskinen, Anni 2007: Kansakoulun kasvitarha- ja maatalousopetukseen liitetyt ihanteet ja tavoitteet 1898-1939. Suomen historian pro gradu -tutkielma. Joensuu: Joensuun yliopisto.

Liikanen, Ilkka 1987: Kansanvalistajien kansakunta. - Alapuro, Risto, Liikanen, Ilkka, Smeds, Kerstin \& Stenius, Henrik (toim.), Kansa liikkeessä. Helsinki: Kirjayhtymä. 126-141. 
Lindgren, Erik 1918: Kasvitarhakirja. Neuvoja keittiökasvien, hedelmäpuiden, marjapensasten, puistopuiden ja -pensaiden, ulkoilma- ja huonekukkien viljelemiseen, ohjeeksi jokaiselle kasvitarhanhoidon harrastajalle. Seitsemännestä tarkastetusta ja lisätystä painoksesta Suomen oloihin mukaillut Klas Stening, Mustialan puutarhuri. Suomentaneet K. Korpela, Aug. Viksten ja K. Ruhanen. 4. p. Porvoo: Werner Söderström Osakeyhtiö.

Löfström, Jan 1999: Sukupuoliero agraarikulttuurissa. "Se nyt vaan on semmonen". Helsinki: SKS.

Merivuori, Tuula-Maria 2001: Bengt Schalin ja vuosisadan alun muotopuutarha. - Häyrynen, Maunu, Eskola, Taneli, Frondelius, Satu \& Leskinen, Pekka (toim.), Hortus Fennicus - Suomen puutarhataide. Helsinki: Viherympäristöliitto ry ja Puutarhataiteen seura ry. 256268.

Mikkola, Kati 2009: Tulevaisuutta vastaan. Uutuuksien vastustus, kansantiedon keruu ja kansakunnan rakentaminen. Helsinki: SKS.

Mäkelä-Alitalo, Anneli 2003: Karjataudit ja eläinlääkintä. - Rasila, Viljo, Jutikkala, Eino \& Mäkelä-Alitalo, Anneli (toim.), Suomen maatalouden historia I. Perinteisen maatalouden aika esihistoriasta 1870luvulle. Helsinki: SKS. 579-597.

Mäkinen, Ilkka 2003: Lukemisen historiaa. - Kervanto Nevanlinna, Anja \& Kolbe, Laura (toim.), Suomen kulttuurihistoria 3. Oma maa ja maailma. Helsinki: Kustannusosakeyhtiö Tammi. 310-325.

Niemelä, Jari 1996: Lääninlampureista maaseutukeskuksiin. Maaseutukeskusten ja niiden edeltäjien maatalousneuvonta 1700-luvulta 1990-luvulle. Helsinki: Suomen Historiallinen Seura ja Maaseutukeskusten liitto.

Niemelä, Jari 2003: Maatalousneuvonta ja -koulutus. - Rasila, Viljo, Jutikkala, Eino \& Mäkelä-Alitalo, Anneli (toim.), Suomen maatalouden historia I. Perinteisen maatalouden aika esihistoriasta 1870luvulle. Helsinki: SKS. 480-492.

Nieminen, Hannu 2001: Sata vuotta eläinten puolesta. Kertomus Suomen Eläinsuojeluyhdistyksen toiminnasta 1901-2001. Helsinki: Suomen eläinsuojeluyhdistys.

Ollila, Anne 1993: Suomen kotien päivä valkenee... Marttajärjestö suomalaisessa yhteiskunnassa vuoteen 1939. Helsinki: Suomen Historiallinen Seura.

Piirainen, Marjukka [tulossa]: Kaswutarha: hyötyä, huwitusta ja siweyden tuntoa. 
Pöyhönen, Nora \& Pöyhönen, Maiju 1950: Kodin kasvitarha. Opas keittiökasvien, marjain, hedelmien, koristepuiden ja -pensaiden, avomaan kukkien ja huonekasvien viljelemiseen. Kuudes, uusittu painos. Helsinki: Kustannusosakeyhtiö Otava.

Rasila, Viljo 2004: Yleiskatsaus Suomen maatalouden historiaan esihistoriasta EU-aikaan. - Markkola, Pirjo (toim.), Suomen maatalouden historia III. Suurten muutosten aika. Jälleenrakennuskaudesta EU-Suomeen. Helsinki: SKS. 474-489.

Ruoff, Eeva 2003: Kotipuutarhat, kasvimaat ja kodin viherkasvit. Kervanto Nevanlinna, Anja \& Kolbe, Laura (toim.), Suomen kulttuurihistoria 3. Oma maa ja maailma. Helsinki: Kustannusosakeyhtiö Tammi. 118-120.

Ruoff, Eeva 2007a: Smirnoff, Alexandra. Kansallisbiografiaverkkojulkaisu. Helsinki: SKS. [online]. < http://www.kansallisbiografia.fi/kb/artikkeli/4698/> [28.7.2014.]

Ruoff, Eeva 2007b: Pöyhönen, Nora. Kansallisbiografia-verkkojulkaisu. Helsinki: SKS. [online]. <http://www.kansallisbiografia.fi/kb/artikkeli/5003/> [28.7.2014.]

Savolainen, Raimo 2008: Grotenfelt, Nils. Kansallisbiografiaverkkojulkaisu. Helsinki: SKS [online]. < http://www.kansallisbiografia.fi/kb/artikkeli/7588/> [16.9.2014.]

Simonen, Seppo 1961: Suomen puutarhatalouden historia. Helsinki: Puutarhaliitto.

Sinnemäki, Aino 1991: "Kun herra maksaa laskun, katselkaa muualle." Sadan vuoden tapasuositukset Suomessa. - Sosiologia 28(3): 176191.

Stark, Laura 2011: The Limits of Patriarchy. How Female Networks of Pilfering and Gossip Sparked the First Debates on Rural Gender Rights in the 19th-Century Finnish-Language Press. Helsinki: Finnish Literature Society.

Stark, Laura 2013: Vanhat sanomalehdet uutena lähdeaineistona kansan elämän tutkimuksessa. - Hovi, Tuomas, Hänninen, Kirsi, Leppälahti, Merja \& Vasenkari, Maria (toim.), Vieras matkassa, vara laukussa. Näkökulmia kansanperinteen tutkimukseen. Turku: Turun yliopisto. 229-254.

Talve, Ilmar 1990: Suomen kansankulttuuri. Helsinki: SKS.

Tommila, Päiviö 1983: Tiedon leviäminen. - Tommila, Päviö, Reitala, Aimo \& Kallio, Veikko: Suomen kulttuurihistoria II. Porvoo: WSOY. 254-293. 
Tuomi, Jouni, \& Sarajärvi, Anneli 2004: Laadullinen tutkimus ja sisällönanalyysi. Helsinki: Tammi.

Tuorlahti, V. 1943: Mustiala 1840-1940. 100 vuotta maatalousopetusta. Forssa: Forssan Kirjapaino Oy.

Valonen, Kari 1991: Suomen maatalouslehdistö. - Tommila, Päiviö (toim.), Suomen lehdistön historia 9. Aikakauslehdistön historia. Erikoisaikakauslehdet. Kuopio: Kustannuskiila Oy. 263-315.

Vihola, Teppo 1991: Leipäviljasta lypsykarjaan. Maatalouden tuotantosuunnan muutos Suomessa 1870-luvulta ensimmäisen maailmansodan vuosiin. Helsinki: Suomen Historiallinen Seura.

Östman, Ann-Catrin 2004: Mekanisoinnin ensimmäinen aalto. - Peltonen, Matti (toim.), Suomen maatalouden historia II. Kasvun ja kriisien aika 1870-luvulta 1950-luvulle. Helsinki: SKS. 19-76.

Filosofian tohtori Taija Kaarlenkaski tekee perinteentutkimuksen post doc -tutkimusta Itä-Suomen yliopistossa Joensuussa.

Filosofian maisteri Marjukka Piirainen on perinteentutkimuksen jatko-opiskelija Itä-Suomen yliopistossa Joensuussa ja tekee puutarhakulttuuria käsittelevää väitöskirjaa. 